\title{
Foreign Shareholdings Impact on Banks Efficiency and Moderating Role of Corporate Governance
}

\author{
Aswin Rivai, Rina Indiastuti, Nury Effendi, Kemal Hidayat, Maman Setiawan
}

\begin{abstract}
The research investigate the impact of foreign shareholding originated from developed and developing countries on the efficiency of acquired local banks in Indonesia during 2007-2017 by including Corporate Governance as a moderating variable. Methodology: Using the secondary aggregate data of 29 commercial banks acquired by foreign shareholders, a panel regression model using econometrics methods of GLS, and DEA were applied to examine the effects of percentage of foreign shareholdings on efficiency of the acquired local banks. The main findings; First, percentage of foreign shareholdings positively affecting efficiency of acquired local banks only if the foreign shareholders is originated from developed countries. Second, the level of economic advancement of the country of origin of foreign shareholders has significant effects on the efficiency of the acquired local banks. Third, the increase in the size of the Board of Directors tends to decrease the efficiency of the acquired local banks and fourth, the presence of Foreign Director has a positive moderating effect on strengthening the effect of percentage of foreign shareholdings on the efficiency of the acquired local banks. Overall, the originality of this studies is that the percentage of foreign shareholdings and its country of origin are two combined factors that cannot be separated in affecting the level of efficiency of its acquired local bank and the fact of significant positive moderating effect of Foreign Director. As policy consideration, monetary authority need to perform strict due diligence on prospective foreign shareholders specifically originated from developing countries, advise banks to maintain the existence of Foreign Director and to encourage small local banks to be merged prior to the acquisition by foreign shareholders.
\end{abstract}

Index Terms: Efficiency, Foreign Shareholdings, Corporate Governance, Agency Theory, Resource-Based Theory.

\section{INTRODUCTION}

In recent years, the relationship between ownership and performance in the banking industry has been developed in

Revised Manuscript Received on September 22, 2019.

Aswin Rivai, Doctorate Candidate, Department of Economics, Faculty of Economics and Business, Padjadjaran University, Bandung, Jawa Barat, Indonesia. aswinrivai@yahoo.com, aswin16001@ mail.unpad.ac.id

Rina Indiastuti, Professor, Department of Economics, Faculty of Economics and Business, Padjadjaran University, Bandung, Jawa Barat, Indonesia.rina.indiastuti@unpad.ac.id

Nury Effendi, Professor, Department of Economics, Faculty of Economics and Business, Padjadjaran University, Bandung, Jawa Barat, Indonesia. nury.effendi@unpad.ac.id

Kemal Hidayat, Senior Lecturer, Department of Economics, Faculty of Economics and Business, Padjadjaran University, Bandung, Jawa Barat, Indonesia.kemal.hidayat@unpad.ac.id

Maman Setiawan, Lecturer, Department of Economics, Faculty of Economics and Business, Padjadjaran University, Bandung, Jawa Barat, Indonesia. maman.setiawan@unpad.ac.id the literature (Altunbas, Yener, Lynne Evans, and Philip Molyneux, 2007). The performance of the banking industry is seen from the level of efficiency achieved by the bank. There are two aspects mostly reviewed, the structure of bank shareholdings and theory applied to study the problem occurred.

The study made by Havrychyk, 2006 found that numbers of foreign banks acquiring local banks tend to have decreasing efficiency which signaling the occurrence of the structural problem in local banks that affecting the foreign banks. Lesson learned is that the acquisition of local banks cannot be done instantly as the country of origin of the foreign shareholders which is the source of the different resources including high skilled worker/ expert, advanced technology, etc need to be further scrutinized. Therefore, the thorough due diligence needs to be implemented prior to acquiring the local bank to avoid negative performance of the acquired bank in the future. Furthermore, the banks acquired by foreign shareholders need to be strictly regulated to avoid negative bank performance impacts as resources in terms of expertise, management skills, and advanced technology of the country of origin of the foreign shareholders and percentage of foreign shareholdings are various and not of the same level. The study made by Rose and Hudgins, 2013 concluded that regulations inhibit the production efficiency and profitability of the banks. Conversely, the study by Fanta, 2013 conclude that Good Corporate Governance minimizes agency cost and increase the efficiency of the banks and ultimately improve bank operational and financial performance (Fanta, 2013).

The phenomena of increasing foreign shareholding in the banking industry and the unclear effect or its impacts on banking performance are used as a basis of the research to be executed. Table 1 detailed several foreign shareholdings portion and efficiency of acquired local banks based on country of origin.

TABLE 1: FOREIGN SHAREHOLDINGS BASED ON COUNTRY/GROUP OF COUNTRY OF ORIGIN

\begin{tabular}{|c|c|c|c|}
\hline $\begin{array}{l}\mathbf{N} \\
\text { o. }\end{array}$ & $\begin{array}{l}\text { Country/Group of } \\
\text { Country }\end{array}$ & $\begin{array}{l}\text { Shareholdings ( } \% \text { ) } \\
\text { based on } \\
\text { Country/Group of } \\
\text { Country of Origin. }\end{array}$ & $\begin{array}{l}\text { Cost - } \\
\text { Income } \\
\text { Ratio }\end{array}$ \\
\hline 1 & Qatar \& Kuwait & $1.38 \%$ & $137.94 \%$ \\
\hline 2 & India & $1.75 \%$ & $235.20 \%$ \\
\hline 3 & China & $3.97 \%$ & $80.5 \%$ \\
\hline
\end{tabular}




\begin{tabular}{llcc}
4 & Japan\& Korea & $8.21 \%$ & $81.35 \%$ \\
5 & Singapore \& Malaysia & $6.82 \%$ & $79.25 \%$ \\
6 & Europe, Australia & $6.96 \%$ & $58.71 \%$ \\
7 & USA & $4.30 \%$ & $60 \%$ \\
8 & Total & $34.39 \%$ & \\
\hline \multicolumn{2}{c}{ Source: 4 ${ }^{\text {th }}$ Published Bank Quarterly Report 2016 }
\end{tabular}

Table 1. shows that higher concentration of shareholdings originated from Japan, Korea, US, and Europe, tends to have higher efficiency. Previous studies such as Hadad et al., 2008 Putri and Lukvirman, 2008, showed that a higher concentration of foreign shareholding by disregarding the country of origin tends to affect the efficiency of the banks. The second phenomenon derived from table abovementioned is that countries grouped as developed countries i.e. Japan, Korea, etc tend to have better efficiency compared to that originated from developing countries i.e. India, Kuwait, Qatar. These studies only study impacts of foreign shareholdings on bank's efficiency as a whole regardless of studying the impacts of foreign shareholdings on efficiency based on its different proportion/concentration of shareholding and level of country economic development. The previous study also did not incorporate Corporate Governance in its models whereas based on agency theory it has a significant role to minimize the agency cost and eventually increase company or bank performance including efficiency. Claessens, 2006 conclude that implementation of Good Corporate Governance will increase efficiency. The research to find evidence to explain the phenomenon that higher portion of foreign shareholdings in local banks and entering of foreign shareholders in shareholdings of local bank originated from more developed countries will increase the efficiency of the acquired local banks in Indonesia for the best of our knowledge is still scanty. Therefore, research related to impact of foreign shareholdings on bank's efficiency in the Indonesian economy and their relationship would contribute to the literature. In the study to be executed the role of Corporate Governance will be observed whether the variable has tendency to become a moderating factor to strengthen or to weaken the impacts of foreign shareholdings on the efficiency of the acquired local banks.

The research questions to be addressed in this study is first, whether the percentage or portion of foreign shareholdings affects the bank efficiency. The second question to be answered is whether the country economic development of the foreign shareholders affects the efficiency of the acquired local banks and the third question to be answered is whether Corporate Governance represents as moderating factor by strengthening or weakening the relationship between foreign shareholdings and bank efficiency.

In this paper, we will develop a formal model to analyze the impacts of foreign shareholdings concentrations on bank efficiency based on the country of origin of investment banks by including Corporate Governance as a moderating factor. The model is tested using recently available data from the Indonesian Banking Directory.

Based on the background abovementioned the objectives of this research is to study the effect of foreign shareholdings on acquired local banks efficiency by first, analyzing the percentage of foreign shareholdings according to their countries of origin to evaluate the validity of the

resource-based theory and the agency theory. Based on agency theory, to improve bank efficiencies, foreign shareholders must hold a substantial amount of shares (Chan, 2016). Second, in regard to resource-based theory, the foreign shareholders, who are from different countries of origin, would contribute differently in terms of its management competence and financial resources. Based on resource-based theory, competitive company should have foreign shareholders owning superior resources such as technology, equity, management skills, and international transactions expertise. Thus, foreign shareholders should originate from country that more developed than the host countries (Chan, 2016). Since foreign shareholders of the local bank in Indonesia may originate not only from developed nations but also from other developing countries, it is important to categorize their countries of origin as resources allocation may be differently allocated. And third, is to examine the impacts of Corporate Governance in moderating the relationship between Foreign shareholdings and efficiency of the acquired bank whether it is strengthening or weakening the relationship. This is because the purpose of encouraging foreign shareholdings in the domestic banking sector is to enhance the governance of the banks so as to achieve better performance.

So, briefly purpose of this research is to bridging the abovementioned research gap which previously did not study the impacts of different portions of foreign shareholdings, different level of country economic development, technology, expertise and organization skills of the foreign shareholders on bank efficiency, and lack to incorporate the functioning of Corporate Governance as a useful factor to provide insight on how foreign shareholdings affect acquired bank efficiency.

The research would contribute the followings; First, to assess the applicability of agency theory and resource based-theory in explaining the impacts of foreign shareholdings from a different country of origin on the efficiency of acquired local banks in Indonesia. Second, policy maker or monetary authority will have a 'screening tools' to decide which countries are eligible or acceptable to acquire local banks based on the financial performance, technological advancement, management expertise and its contributions for improving the efficiency of the banking industry in Indonesia. Nevertheless, policy maker or monetary authority need to be vigilant in issuing the regulations by avoiding excessive strict regulation such as strictly limited the foreign shareholdings portions as eventually, it will inhibit the potential income and efficiency of the banks. Third, policy maker or monetary authority may decide whether the foreign shareholders is majority shareholder or controlling shareholder in order to safeguard the smoothness of implementation of its technology and management expertise to increase the efficiency of the banks. Fourth, results of this study may be used as reference to confirm whether the portion of foreign shareholdings need to be restricted at certain level of percentage in Indonesia considering that foreign shareholders are very concern on its status as controlling shareholders to safeguard their authority in directing the management strategy, usage of skills, technology required to strengthening the bank 
performance including its efficiency.

\section{LITERATURE REVIEW}

Empirical results show the company's performance can be affected by the ownership structure of the company. Efficiency is included in the company's performance. Here we present a plethora of empirical results regarding the relationship between ownership structure and bank efficiency. The ownership structure of different banks will provide a different level of efficiency for each bank (Awdeh and El Moussawi 2009; Shaher et al. 2011). The research results on banks in the State of Lebanon from 1996 to 2005 showed that the majority of foreign-owned banks have greater improvement in efficiency levels compared with the majority of locally owned banks. In other words, locally owned banks have a weaker performance than foreign-owned banks.

Further research showed that the performance of the company is not determined by the ownership structure but rather depends on the company manager (Hadad et al. 2003). Results of research by Hadad et al. (2003) show no link between the structure of ownership in Indonesian banks with the bank's performance.

McAllister and McManus (1993; in Iannotta et al. [2006]) showed that the major banks have an opportunity to diversify risk; thus, major banks have a lower cost of funds compared with small banks. Large banks tend to earn higher net interest income compared with smaller banks. This fact is associated with high economies of scale in large banks compared with small banks because cheaper funds are more easily obtained in the money market. In addition, the level of market and the public confidence to entrust their funds to large banks is higher than for small banks. Despite that cost of funds is lower for large banks than small banks, more people tend to save their money in large banks. Thus, the economies of scale or size in banking are positively correlated with efficiency.

According to economic theory, the relationship between input and output changes is described in terms of increasing returns to scale, decreasing returns to scale, and constant returns to scale (Pindyck and Rubinfield 1995). Large banks with increasing returns to scale have higher levels of efficiency than smaller banks. In contrast, large banks with decreasing returns to scale have a lower level of efficiency than smaller banks. In conditions of constant return to scale, large banks and small banks have the same level of inefficiency.

Based on the previous discussion, the effect of foreign shareholdings on a bank's efficiency may be explained by the agency and resource-based theories. The agency theory concludes that foreign shareholders may enhance efficiency by reducing the risk of controlling shareholders' manipulation (Dharwadkar, George, and Brandes 2000), as was evidenced in China (Hasan and Xie 2013; Lin and Zhang 2009) and the United States, (Kang and Kim 2010). Next, the resource-based theory concludes that the use of unique or better technology and other quality resources may enhance bank efficiency. The shortage of demand of quality products and services has been produced by foreign shareholders including financing, organizational and management expertise, technology, and international networking. (Dunning 1988; Douma, George, and Kabir. 2006; Meyer et al. 2009).

Despite the empirical results abovementioned, the contribution of foreign shareholdings toward bank performance is not yet having decisive results. For example, $\mathrm{Wu}$, Chen, and Lin (2007) found that Chinese banks' performance deteriorated with the inclusion of foreign shareholders. Conversely, studies of listed firms in Indonesia (Wahyuni and Prabowo 2012) and Vietnam (Phung and Lee, 2013) found that foreign shareholdings enhance firm performance if the foreign investors hold the largest or the second-largest number of shares.

The concentration of foreign shareholding affects the level of capacity in making decision and governance so that often one of the requirement to acquire a local bank in host country banks. Majority shareholdings are one of the objectives (Whitley and Kristensen 1996; Gedajlovic, Yoshikawa, and Hashimoto 2004; Chhibber and Majumdar 1999; Wahyuni and Prabowo 2012). For this reason, Gedajlovic, Yoshikawa, and Hashimoto (2004) found no significant contribution of the foreign investors who had only minority interests in terms of financial performance and risk management of 247 of the largest Japanese firms.

The foreign investor's country of origin is important because the resource-based theory suggests that bank performance improves due to superior resources. This assumes that investors who help enhance a bank's efficiency are from more advanced countries. An investor from a country no more developed than the host country is unlikely to have such a salutary effect. (Chan, 2016)

Corporate Governance which is based on Agency Theory is functioning to minimize the agency problem and eventually improve company performance. Agency problems are highly correlated with corporate governance. Both external and internal corporate governance systems provide a monitoring function in management decisions $(\mathrm{Wu}, \mathrm{Lin}$ and Yang, 2016). Organization for Economic Co-operation and Development (OECD) defines corporate governance as "a system to direct and control the corporation". Corporate Governance is any structured system of allocating power in a corporation that determined how and by whom the company is to be governed (Frederick, et al., 1992). Corporate Governance is the overall control of activities in a corporation. It is concerned with the formulation of long-term objectives and plans and the proper management structure (organization, systems, and people) to achieve them (Steiner, 1997).

Soba, Erem, and Ceylan (2016) study the effect of corporate governance on corporate performance in Turkey. The effect of corporate governance on the company or bank performance is mixed (Beisland et al., 2014). The effects are highly dependent on contextual factors as well as the measures of corporate governance and firm performance. Bhagat and Bolton, 2008 conclude that evaluation of Corporate Governance by using one variable econometric wise is more accurate as the error of estimation of one variable is smaller than using multivariable or index. No index or variables that can accurately explain the relationship between Corporate Governance and 
firm performance as it depends on context and specific characteristic of the firm of different nuances. It is better to use one single variable such as the presence of Foreign Director as a focus of the study is on foreign shareholdings. The effectiveness of Corporate Governance on Banks mostly depend on the Composition of the Board of Directors and its Shareholdings. Overall, the Board of Directors is a tool to overcome the weakness of managers. (Adjaoud er al.2007).

Hermalin and Weisbach, 2003 conclude that Board of Directors is the heart of Governance. Factors affecting the Board of Directors is numbers of Director, the availability of independent/ foreign Director. Appointment of Foreign Director as a member of the Board of Directors is a sign for improvement of governance which motivates foreign shareholders to own the Bank or company (Kim, et al, 2010). The study by Hajer, 2016 on eight commercial banks in Tunisia period 2000-2011 concluded that the Board of Directors composition and percentage of foreign Director in BOD and bank assets has no effect on the efficiency of the bank.

G.A.Bokpin (2013) found that higher numbers of a member of the Board of Directors will increase cost efficiency. Conversely, Belkhir, 2005 conclude that the bigger composition of Board of Directors will improve bank performance. Liang et al, 2013 conclude that Foreign Director and Commissioner brought technology and management skills that improve Bank performance.

The study to be done attempt to fill the research gap by examining the potential effect of foreign shareholders' concentration and origin on bank efficiency.

\section{METHODOLOGY}

We adopt a non-parametric approach, the Data Envelopment Approach (DEA), to estimate the efficiency of the local banks acquired by foreign shareholders. We further incorporate the percentage of foreign shareholdings of the local banks to examine its influence on efficiency.

We also adopt the profitability approach to determine the input and output vectors for estimating efficiency instead of intermediation or production approach due to the; First, Drake et al, 2009 conclude that profitability approach will give more comprehensive analysis because different interest rate factor and risk transfer factor has been included in the analysis. Whereas other approach does not incorporate the different interest rate factor completely and lack of including the risk transfer.

Second, Berger \& Humphrey (1997) conclude that the production approach is better used to evaluate branch of the financial institution instead of the whole institutions. Whereas according to Allen and Santomero, 1998, intermediate approach is more focusing on less important function and product of the financial institutions as this approach does not include the risk transfer and complex banking instruments/products in the market. Loan loss provision has been generally accepted as a risk proxy in the estimation of efficiencies of banks (Sun and Chang, 2011). In profitability approach, three inputs will be used such as deposits expense, fixed asset expense including loan loss provision and personnel expenses, whereas for outputs the item is loan interest income, other productive assets income ( marketable securities, bonds, fund placement in other banks) and other non-interest income. Efficiency is calculated as the ratio of output on input as below.

$\mathrm{x}$ and $\mathrm{y}$ represent input and output, $\mathrm{i}$ and $\mathrm{j}$ represent certain input and output. So, $x i$ is input -ith and yj is output -jth at Decision Making ( DMU). Total input represents by I and total output represent by $\mathrm{J}$, where $\mathrm{I}, \mathrm{J}>0$. Mathematical equation presented as below,

Virtual Input $=\sum \underset{\mathrm{t}=1}{\mathrm{j}} \mathrm{xt}$

ui is weighted of input xi during the accumulation process,

Virtual Output $=\Sigma$ yvj

$\mathrm{t}=1$

$\mathrm{vj}$ is weighted of input yi during the accumulation process,

Efficiency $=\frac{\text { Virtual Output }}{\text { Virtual Input }}=$
$\frac{\sum_{\mathrm{j}=1}^{\mathrm{J}} \mathrm{yvj}}{\underset{\substack{\mathrm{I}=1 \\ \text { ut } \mathrm{xt}}}{ }}$

Data will be processed using the DEAP 2.0 and EViews 10.0. Efficiency scores during the period of study will be regressed against several internal factors independent variables such as total assets, the strength of capital measured by Capital Adequacy Ratio (CAR).

\section{A. Sample and Data}

The sample for this study consists of locally controlled commercial banks acquired by foreign shareholders in Indonesia and the data is sourced from Directory of Indonesian Banking 2007-2017.

Our data set covers twenty-nine domestic commercial banks acquired by foreign shareholders, which yields a sample of 319 observations. Our sample starts from 2007 that is, the years in which many local banks were acquired by foreign shareholders after the issuance of government regulation to ease the maximum limit or cap of foreign shareholding in the local/domestic bank to $99 \%$ in 1999 . This ensures that all the domestic commercial banks are banks acquired by foreign shareholders as before 2007 most of the local banks is still owned by domestic shareholders, therefore, this is a balanced panel because we try to maintain as many banks as possible in this study to derive a better representation of how the foreign shareholdings affect efficiencies. We also filter the sample to include only banks with at least 11 years data so as to obtain a smoother and better estimation of the efficiencies. The data, as well as the percentage of foreign shareholdings, are extracted from various banks' financial statements downloaded from Directory of Indonesian Banking sourced from Bank Indonesia, the central bank of Indonesia Data on the macroeconomic variables is 
obtained from the Indonesia's Central Bureau of Statistics.

\section{B. Definition of Variables}

There are three main independent variables and five control variables that affect the efficiency of the bank. The main independent variables are percentage of shareholdings of (i) developed countries (Japan, Korea, Singapore, Taiwan, France, United Kingdom, Germany, Netherlands, Australia and Malaysia), (ii) China, and (iii) developing countries (India, Qatar, Kuwait,) The moderating variables are (iv) number of member of the Board of Directors (CGD), and (v) number of total Foreign Director (GGF).

China is standalone or separated from both group because even though China per capita income is categorized as a developing country but the capital and financial capacity and level of technological advancement have leveled off the developed countries. Malaysia is categorized as a developed country in this study due to its knowhow index or proportion of high skills worker based on WEF-Global Human Capital Reportk/ 2017 is more or less in the same level as that of the developed countries and even exceeding Australia.

The other five control variables are (i) Capital Adequacy Ratio, (ii) Asset, (iii) Inflation growth, (iv) growth of GDP, and (v) Return on Assets of the previous one year $(\mathrm{t}-1)$. (Return On Assets is estimated as a ratio of Earning Before Tax divided by bank's average assets).

The main focus of this study is to design model that can explain the effect foreign shareholding concentration based on its country of origin which is strengthened or weakened by Corporate Governance proxy by number/size of Board of Directors (BOD) and the number of Foreign Director. As differs from the previous study by Rokhim, 2013 which study the effect of the increase in foreign shareholding on the performance of commercial banks as a whole by including the banks with minor or without foreign shareholdings, the study to be executed is only focusing on banks acquired by foreign shareholders to obtain more accurate results.

It is expected that first, a higher percentage of foreign shareholding or majority shareholders will contribute significant impacts on efficiency. Second, Foreign shareholders from developed countries with better resources (technology, equity, management skills, international transactions expertise) will increase efficiencies as shareholders originated from countries with the same level of economic development with that of the host country tends not to increase the efficiencies. Capital adequacy ratio based on previous research is significantly affecting the efficiency of the banks (Saha et al, 2015). Besides shareholdings percentage variables, the model also employs Corporate Governance as a moderating variable which is proxy by numbers of the member of BOD and numbers of Foreign Director. Based on previous research, Agency Theory and Resource-Based Theory, both variables are part of resources representing management skills which strengthening and weakening the bank performance including efficiencies.

Based on previous study assets affects efficiency due to the economy of scale. We control for bank size measured by the natural logarithm of the individual banks' total assets. Other macroeconomic variables used is inflation growth as it is required to control prices increases of input and output of production factors due to inflation. GDP growth variable is an indicator of macroeconomics cycle which affecting bank performance specifically efficiencies. High GDP growth implies better country economic growth; hence, banks that can set higher price may attain a higher efficiency level that will strengthen the bank performance. Return on Assets (ROA) also includes in this model as control variable as the higher the bank profitability, the higher the potentiality of banks to allocate its resources more efficiently (Chan, 2016). We also control for the country's inflationary experience because higher inflation rates may increase the prices of input factors. Efficiency variable will be estimated using DEA (Data Envelopment Analysis).

Efficiency estimated using DEA is more accurate than Cost Income ratio as input and output of each bank has its own unique characteristics so that cannot be compared directly with other banks. The characteristic includes size, shareholdings ownership, management competence, technology, etc. By using DEA bank efficiency is compared relatively with the most efficient bank without affected by the different characteristics of those banks. Based on variables definitions abovementioned, the efficiency function of the bank with foreign shareholdings can be explained as

\section{Eff $=\mathrm{f}($ Dev, China, Deving, CGF, CGD, CGFDev, CGFDeving, CGDDev, CGFDeving, ROAt-1, Asset, CAR, Inf, RGDP),}

The hypotheses of the research are as below,

H1: Percentages of foreign shareholdings is positively correlated to the efficiency of the acquired bank.

$\mathrm{H} 2$ : The more developed the country of origin of the foreign shareholders, the higher the efficiency of the acquired local bank.

H3: Corporate Governance tends to strengthen the correlation between foreign shareholding and efficiency of the acquired local banks

\section{Model Specification}

In this study the new model is designed which is a modification and development of model used by Rokhim, 2013 which analyze the effects of foreign shareholdings ratios on profitability, efficiency and risks, and also utilizing models used by Hajer, 2016 and Uang, 2015 which study the effect of Corporate Governance on efficiencies and profitability, and finally using the model used by Rachdi, 2013 which study the effect of Corporate Governance on Credit Risks. As opposed to studying by Rokhim, 2013, this research will use DEA to estimate the efficiency which method is more accurate due to the efficiency of each bank is estimated comprehensively by considering factors such as strategy, type and scale of business of each bank relatively to best practice bank which has the highest efficiencies. In the study to be done, the ROA is also added in the model as based on the study made by Wen \& Chan, 2016 conclude that the higher profitability will enable to have a better capacity to allocate its resources more efficiently.

Thus, to analyze the effect of foreign shareholdings on efficiencies of the acquired local banks, the hypotheses abovementioned is tested by applying the following model.

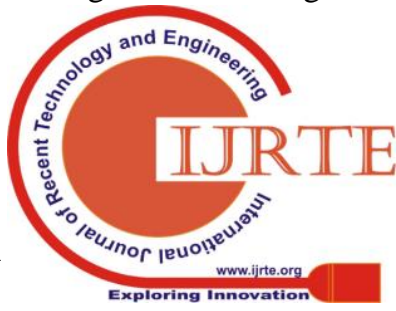




\section{Effit $=\beta o+\beta 1$ Dev it $+\beta 2$ Deving it $+\beta 3$ China it + B4CGDit $+\beta 5$ CGFit $+\beta 6$ CGDDevit + $\beta 7$ CGDDevingit $+\beta 8$ CGDChinait + $\beta 9$ CGFDevit $+\beta 10$ CGFDevingit + $\beta 11$ CGFChinait $+\beta 12$ ROAit $-1+$ $\ln \beta 13$ ASSETit $+\beta 14$ CARit $+\beta 15 \mathrm{INF}+$ $\beta 16 \mathrm{RGDPt}+\beta 17 \mathrm{D}+\varepsilon 1$}

Whereas:

Effit is the efficiency of bank $i$ at year t estimated by using Data Enveloped Analysis (DEA)

Dev is percentage ratio of foreign shareholding of developed countries in bank $\mathrm{i}$ at year $\mathrm{t}$.

Deving is percentage ratio of foreign shareholding of developing countries at bank $i$ at year $t$.

China is percentage/proportion ratio foreign

shareholding of China in bank $\mathrm{i}$ at year $\mathrm{t}$.

ROAt-1 is the profitability of previous one year of bank $i$ at year $t$ as time lag of approximately 1year is required by bank to allocate its resources efficiently to obtain higher profit.

ASSET is the number of assets of bank $i$ at time $t$.

CAR is the ratio of the capital on risk-weighted asset of bank $\mathrm{i}$ at year $\mathrm{t}$.

CGD is numbers of the member of Board of Directors

(BOD).

CGF is numbers of foreign Director.

CGDDev/Deving is moderating variable of numbers of BOD.

CGFDev/Deving is moderating variable of Foreign Director.

INF is inflation growth in year $t$.

RGDP is GDP growth in year t.

$\mathrm{D}$ is the Dummy variable to see the efficiencies of the acquired local bank after global crisis. $D=0$ (2007-2008) and D $=1$ (2009-2017).

\section{RESULTS AND DISCUSSIONS}

In general, the variables in this study is presented in a statistical description detailed in table 2 to provide a general understanding of all variables to enable easy comprehension and informative for readers. The statistical description includes maximum and minimum average, and the standard of deviation of each variable used in the regression model.

Appendix A shows that the average CAR is $24.897 \%$ and the highest is $206.61 \%$ which is CAR of BNP Paribas in 2009. The high CAR of the bank is due to a decrease in credit extended to the borrower to become IDR 80.1 Billion which in the previous year the credit extended to borrower reached IDR 952 billion. The lowest CAR belongs to J Trust Bank in 2011 amounting $9.41 \%$ but generally, all CAR is above minimum CAR requirement of $8 \%$ as required by the central bank.

The average number of the foreign director in local banks acquired by foreign shareholders is 3 or 4 person. The highest is 11 (eleven) which is Danamon Bank, a local bank acquired by foreign shareholders from Singapore. The lowest is zero/ no foreign director in the bank management/board as the bank is not yet acquired by foreign shareholders at that time. The highest number of member of BOD is Danamon Bank, a local bank acquired by shareholders from Singapore which has 21 members of the board of management in 2016. The lowest is Oke Bank in 2017 a bank acquired by South Korea shareholders, and J Trust Bank, a bank acquired by shareholders from Japan in 2007-08. Appendix B shows efficiency of each bank estimated by using Data Envelopment Analysis (DEA).

The average efficiency of local bank acquired by foreign shareholders during 2007-2017 is 0.728 and the most efficient banks originated from Taiwan (CTBC), South Korea (Hana, Woori) and Japan (SMBC) with average of efficiency almost 1.000, whereas the most inefficient is banks originated from Middle East such as Muamalat and QNB Kesawan which average efficiency less than 0.6. The study by Barry, 2013 also found that banks originated from South Korea is very efficient. In general, the average efficiency of local banks acquired by foreign shareholders is still not efficient (0.728) and only $24.45 \%$ of all local bank acquired by foreign shareholders is efficient (1.000).

The descriptive statistic data abovementioned, indicated by the maximum values, shows that several observations value is exceeding far beyond the average value thus the Ordinary Least Square regression become invalid due to a violation of classical assumptions such as heteroscedasticity, multicollinearity, and autocorrelation resulted from the extreme observations value. As we need to use the observations considering the importance of the data for our study, another alternative method is applied to overcome the violations of the assumption abovementioned which is by using Generalized Least Square.

The effect of percentage of foreign shareholding based on the level of country economics development on efficiencies is tested by using General Least Square (GLS) as using the Ordinary Least Square (OLS) will produce the regression coefficients which having violations of classical assumption such as heteroscedasticity and autocorrelation. Except for multicollinearity, the regression model is still violating the classical assumptions so cannot be used as an efficient estimator (BLUE). Thus, the data should be processed using other regression techniques namely Generalized Least Square (GLS) or Weighted Least Square (WLS) as it is transformed using the weighting techniques (Wooldridge, 2010)

GLS is a least square techniques designed to overcome heteroscedasticity which is able to preserve the efficiency of the estimator without losing its unbiased and consistency characteristics. GLS is able to minimize residual square which has been weighted (weighted least square) so it can fulfill the standard assumptions of the least square (OLS) resulting in the BLUE results estimations (Gujarati and Porter, 2012). If the efficiency estimator is more important than unbiased and consistency under the condition of heteroscedasticity, the Estimated Generalized Least Square (EGLS) is more appropriate to be used instead of OLS. Therefore the EGLS method is used to eliminate the heteroscedasticity and autocorrelation (Gujarati and Porter, 2012). The method in which the residual is replaced by moment estimator is also applied here. This method is a variant namely Panel Corrected Standard Error (PCSE) (Beck and Katz, 1995).

TABLE 2: ESTIMATION RESULTS USING EGLS 


\begin{tabular}{|c|c|c|c|}
\hline & Efficiency & t-statistic & Probability \\
\hline $\mathrm{C}$ & $0.506742 * *$ & 2.044 & 0.0418 \\
\hline DEV & $0.100263 * * *$ & 3.279 & 0.0012 \\
\hline DEVING & -0.028224 & -0.749 & 0.4547 \\
\hline China & $-0.733912 * *$ & -2.030 & 0.0432 \\
\hline CGD & $-0.010969 * *$ & -2.037 & 0.0425 \\
\hline CGF & -0.018406 & -1.565 & 0.1184 \\
\hline CGDDEV & $-0.010868 * * *$ & -3.221 & 0.0014 \\
\hline CGDDEVING & $-0.014144 * * *$ & -2.740 & 0.0065 \\
\hline CGDChina & 0.072183 & 1.247 & 0.2134 \\
\hline CGFDEV & $0.025352 * * *$ & 3.221 & 0.0014 \\
\hline CGFDEVING & $0.051853 * * *$ & 2.740 & 0.0065 \\
\hline CGFChina & 0.041118 & 0.395 & 0.6935 \\
\hline ROAt-1 & $0.030183 * * *$ & 6.489 & 0.0000 \\
\hline LNASSET & $0.045563 * * *$ & 2.777 & 0.0058 \\
\hline CAR & 0.000714 & 1.488 & 0.1379 \\
\hline INFL & -0.00236 & -0.632 & 0.5278 \\
\hline RGDP & $-0.050278 * * *$ & -3.385 & 0.0008 \\
\hline D1 & 0.004063 & 0.138 & 0.8901 \\
\hline R square & 0.366023 & & \\
\hline F statistic & 10.2224 & & \\
\hline Prob.(Fstat.) & 0.00000 & & \\
\hline
\end{tabular}

In Appendix C, we perform multicollinearity test on above GLS to ensure no correlations among its independent variables. There is no correlation matrix of the independent variables above 0.80 meaning that there is no multicollinearity occurred in the model. The estimated model above has been cleared from violation of the classical assumption of multicollinearity. By using white-cross and PCSE the heteroscedasticity in standard error (SE) and covariant in previous regression can be eliminated (Wooldridge, 2005).

Based on table 2, it was found that coefficients of foreign shareholders originated from developed countries at a level of confidence of $99 \%$ is positively significant on affecting efficiencies of its acquired local bank. The increase of foreign shareholdings by $1 \%$ using will increase the efficiency of its acquired local banks by $0.1 \%$. As for foreign shareholdings originated from China, is negative and significant. Increase of China shareholdings will decrease the efficiency of local banks by $0.73 \%$ Based on the result above, the first hypothesis mentioning whether the percentage of foreign shareholdings is positively affecting the efficiency is accepted under the condition that the foreign shareholdings should originate from the developed countries. The higher percentage/portion of foreign shareholdings from the developed countries, the higher efficiencies of the acquired local banks. Conversely, the lower the percentage/portion of shareholdings from developed countries will lower its acquired local banks' efficiency.

Based on Appendix A, the average percentage of foreign shareholdings of developed countries of $62.8 \%$ which is relatively high is significantly increasing efficiency. This result is supported by a study by Ozili and Uadiale, 2017 conclude that the high percentage of shareholding on the bank in Nigeria will increase its net interest margin or efficiency.

In terms of foreign shareholders from developing countries as depicted in Appendix A and Table 2, percentage/portion of its foreign shareholdings has no impacts on the efficiency of its acquired local banks. As seen in Appendix A, the average percentage/portion of foreign shareholdings from developing countries is relatively low or $23.4 \%$ so has no impact on efficiency. Therefore it is concluded from this study that the percentage of foreign shareholding will affect the efficiency of its local acquired bank only if the foreign shareholdings is originated from developed countries. This is due to the better managerial skills, expertise, technology, and performance of the developed countries as opposed to developing countries. This is also reflected by IMF 4Q, 2017 data showing that average NPL of developed countries is lower than in developing countries. In the example, average NPL of banks in Korea is $0.42 \%$, Japan is $1.19 \%$ and Taiwan is $0.46 \%$ whereas the average NPL of developing countries i.e. India is $9.98 \%$, and Kuwait is 5.44\%.(IMF, 2018) This result is also consistent with a study by Chan, 2016 on ASEAN banks concluded that the small percentages of foreign shareholdings originated from developed countries i.e. European countries, and the USA has a small impact on the efficiency of its acquired local banks. The percentage/portion of shareholdings of European countries is $4.08 \%$ and from the US is $3.03 \%$.

The results are consistent with the study by Gedajlovic, Yoshikawa, and Hashimoto, 2004 which has found no significant contribution from minority shareholders whereas the high percentage/of foreign shareholdings from China and Developing Countries tends to decrease the efficiency of the acquired local banks. Our research also supports the study by Gedajlovis as seen in table 2 showing that increase percentage of foreign shareholdings from China in its acquired local banks will decrease its efficiency. These findings are also the same with the study by Phung and Lee, 2013 mentioning that percentage/portion of foreign shareholdings will increase company performance only if the foreign shareholders is majority shareholder or at least second highest shareholder. Our study findings overcome previous research gap which only analyzes impacts of increase portion of foreign shareholdings in general without differentiation of the impacts based on the level of country economic development. The study by Rokhim, 2013 on commercial banks concluded that the increase in foreign shareholding in general without differentiating based on country of origin has no impact on cost efficiency (cost-income ratio). This is due to criteria used by Rokhim to categorize local bank owned by foreign shareholders is different as the minimum shareholdings are only $10 \%$ for foreign shareholders, whereas, in this study, the minimum foreign shareholdings are $50 \%$ as to ensure the majority shareholdings or authority in making strategic decisions. Rokhim used BOPO or Cost Income ratio which is disregarding the size, and input/output structures of different banks, whereas in our study the DEA method is used to incorporate the shortages mentioned.

Corporate Governance proxy using the size of the Board of

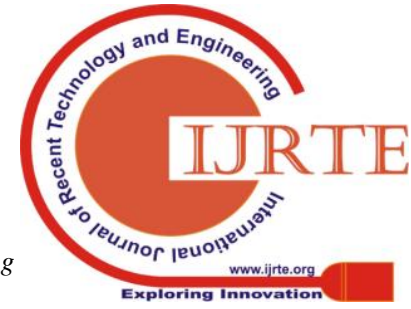


Directors, in general, has a negative impact and significant on the efficiency of acquired local banks. The increase in the size of the Board of Directors will significantly decrease efficiencies of the acquired local banks. These findings is consistent with Jensen agency theory which suggests that smaller board size is beneficial for driving organizational outcomes (Jensen, 1993). However, conversely, other studies find a positive relationship between board size and bank efficiency include Soba et al. (2016) and Bokpin (2013). Abayi et al (2018) also found that the large size of Board of Directors increases the efficiency of the rural banks in Ghana.

In terms of the role of Foreign Director in Bank Board, if differentiated based on country of origin of the foreign shareholders, the increase of number of Foreign Director in the acquired local bank by foreign shareholders from Developed Countries and also Developing Countries will both have positive impacts and significant in increasing efficiency of the acquired banks. These results show that Foreign Director is a significant moderating variable in strengthening the effect of foreign shareholdings on efficiencies of the acquired local banks. Whereas for China, there is no effect on it acquired local banks.

Previous one-year profitability has a positive effect and significant on bank efficiency. An increase of $1 \%$ of last year profit will both increase bank efficiency by $0.03 \%$.

Assets have positive significant effects on the efficiency of the acquired local banks. Bigger bank tends to increase its efficiency. Bigger banks tend to have better infrastructure such as resources, information technology, adequate organization structures and supported by vast office network and more complex products that enable the bank to be more efficient by using certain inputs and producing output such as services to the public, credit extended and placement of other productive assets that creates profit.

The Capital Adequacy Ratio (CAR) and inflation growth have no effect on the efficiency of the acquired local bank by foreign shareholders. This result is contradict with the study by Lotto, 2018 finding that CAR will increase the operational efficiency of banks in Tanzania. Berger \& Patti, 2006 found that the lower CAR will increase the efficiency of banks in the US, whereas, for banks in Europe, Fioderlisi, and Marques-Ibanez, 2013 found that the lower CAR will decrease efficiency. Altunbas et al, 2007 found that the lower CAR in Europe will increase efficiency. This contradicting results according to Berger and, Bonaccorsi in Patti (2006, page 1068) is due to the efficiency is affected by Net Interest Margin (NIM) instead of CAR.

GDP growth has a negative and significant effect on the efficiency of its acquired local bank by foreign shareholders. Increase GDP growth by $1 \%$ will decrease local bank efficiency by $0.05 \%$ using the EGLS and by $0.043 \%$ by using Robust Least Square.

The Dummy variable shows that global crises have no effect on the efficiency of the acquired local bank by foreign shareholders. It is understandable as local banks mostly acquired by foreign shareholders have no significant exposures with banks suffered by the crises.

$\mathrm{R} 2$ of 0.366 means that $36.6 \%$ fluctuation in efficiency can be explained by the independent variables in model whereas the rest is explained by factors beyond the regression model.

\section{CONCLUSION AND RECOMMENDATION}

This research is intended to provide new approach on how foreign shareholdings in Indonesia's banking industry affect the efficiency of its acquired local banks by analyzing the foreign shareholdings percentage/portion and also analyzing its country of origin that till date is still scant. Percentage of shareholdings is an application of agency theory whereas country of origin that has a different level of economic advancement, quality of managerial expertise is based on resources based theory. Findings of this research conclude that the percentage of foreign shareholdings and its country of origin are two factors that cannot be separated in affecting the level of efficiency of the acquired local bank whereas Foreign Directors strengthening its effect on efficiency. Foreign shareholdings positively affecting the efficiency of acquired local banks only if the foreign shareholders is majority shareholders/controlling shareholder and is originating from countries more developed than Indonesia as the host country.

Findings recommend monetary authority or policymakers to consider proper weighted of the three aspects such as country advancement of the foreign shareholders, shareholding significant of the foreign shareholders within the acquired banks and the proper regulation of maximum percentages of foreign shareholdings issued by the policymaker or monetary authority.

Specifically, efficiency can be increased by encouraging foreign shareholders originating from countries that is more advanced than Indonesia as the host country. Policy maker need to perform strict due diligence on the performance of the country of origin of the foreign shareholders including managerial expertise of the candidature of the member of Board of Directors to obtain competence candidates. Furthermore, higher efficiency can be obtained only if the foreign shareholders is a majority shareholder/ controlling shareholders, and lastly, the monetary authority should not issue restrictive regulations such as excessive limitation on maximum percentage of foreign shareholdings that could inhibit in making strategic decisions related to use of its advance management skills, financial capital, and technology and eventually inhibit the process of increasing efficiencies of the banks.

Banks acquired by foreign shareholders from developed countries should minimize numbers of its member of Board of Directors to increase efficiency but the number of Foreign Director should remain unchanged to increase the efficiency of the acquired local bank. Whereas small local banks acquired by foreign shareholders is encourage to be merged to become bigger banks that is more efficient and capable to compete with bigger banks.

For future studies, subject to the availability of the data, it is recommended to perform cross country analysis by including acquired local banks located in other countries to observe whether different characteristics in terms of economic advancement, social and cultural similarities or differences of hosting country matters on efficiencies of the local banks acquired by foreign shareholders. 


\section{REFERENCES}

[1] Abayie, Eric Fosue Ote; Affram, Anthony;Mensah, Kofi Henry.(2018). "Governance and Efficiency of Rural and Community Banks (RCBs) in Ghana”. Economic Research and Finance.Vol3.pp.93-118.

[2] Adjaoud, Fodil; Zegal, Daniel\& Andaleeb, Syed. (2007)."The Effects of Board Quality on Performance: A study of Canadian Firm". Corporate Governance An International Review 15(4):623-635.

[3] Allen Berger and Emillia Bonaccorsi di Patti.(2006). "Capital structure and firm performance : a new approach to testing agency theory and an application to the banking industry".Journal of Banking and Finance. Vol 30.Issue 4, 1065-1102.

[4] Allen, F. and Santomero, A. (1998) The Theory of Financial Intermediation. Journal of Banking and Finance, 21, 1461-1485.

[5] Altunbas, Yener, Lynne Evans, and Philip Molyneux, 2007, "Bank Ownership and efficiency" Journal of Money, Credit, and Banking, 33(4), pp.927-954

[6] Awdeh, A, dan EI Moussawi, C.(2009), "Bank Efficiency and Foreign Ownership in the Lebanese Banking Sector", Review of Middle East Economics a Finance,vol.5, issue 2.

[7] Baghat, Sanjay; Bolton, Brian (2008), "Corporate Governance and Firm Performance", Journal of Corporate Finance", Vol.14(3), p.257-273

[8] Baghat, Sanjay; Bolton, Brian: Romano, Roberta (2007), "The Promise and Peril of Corporate Governance Indices "Columbia Law Review, Vol.108. No.8 lpp.1803-1882.

[9] Bank Indonesia. Bank Indonesia Regulation No. 14/8/PBI/2012 pertaining Ownership in Commercial Banks. State Gazette of Republic of Indonesia Year 2012 No.144 DPNP Annexure of State Gazette of Republic of Indonesia No. 5327 DPNP.

[10] Bank Indonesia (2012). Circular Letter No 15/4/DPNP pertaining ownership in Commercial Banks.

[11] Bank Indonesia (2015), Indonesia's Banking Directory, DPIP, Otoritas Jasa Keuangan-Jakarta.

[12] Belkir, Mohammed. (2006). "Board structure, Ownership structure, and Firm Performance Evidence from Banking".

[13] Berger, Allan N, and David B. Humphrey, 1997, "Efficiency of Financial Institutions: International Survey and Directions for Future Research" Forthcoming in European Journal of Operational Research, January 1997. The Wharton School, University of Pennsylvania.

[14] Beisland, L. A., Mersland, R., and Randøy, T. (2014). "The Association between Microfinance rating scores and corporate governance: a global survey". International Review of Financial Analysis, 35(C):268-280

[15] Bokpin, G. A. (2013). "Ownership structure, corporate governance, and bank efficiency: an empirical analysis of panel data from the banking industry in Ghana. Corporate Governance": The international journal of business in society, 13(3):274-28

[16] Chen, Wenjie,2011, "The effect of investor origin on firm performance: Domestic and foreign direct investment in the United States", Journal of International Economics, 83,pp 219-228.

[17] Chermian Eforis and Jinn-Yang Uang(2015), "Corporate Governance and Firm Performance: The Moderating Effect of State Ownership" Proceedings 4th Global Business and Finance Research Conference 25 May 2015.Melbourne, Australia.

[18] Claessen, Stijn. (2006)." Corporate Governance and Development", World Bank Research Observer Volume 21, Issue 1.Pages: 91 -122

[19] Chhibber, P. K., and S. K. Majumdar. 1999. Foreign ownership and profitability: Property rights, control and the performance of firms in the Indian industry. The Journal of Law and Economics 42:209-38.

[20] Damodar N. Gujarati and Dawn C.Porter.( 2012).Basic Econometrics. Mc Graw Hill.New York.

[21] Dharwadkar, Bavi; George, Gerard; and Brandes, Pamela. Privatization in Emerging Economies: An Agency Perspective. (2000). Academy of Management Review. 25,(3),650-669. Research Collection Lee Kong Chian School Of Business.

[22] Douma, S., R. George, and R. Kabir. 2006. "Foreign and domestic ownership business Group and firm performance: Evidence from a large emerging market”. Strategic Management Journal 27:637-57

[23] Dunning, J. H. 1988. "The eclectic paradigm of international production: A restatement and some possible extensions". Journal of International Business Studies 19:1-31.

[24] Fanta, B. A., Kemal, S. K., \& Waka,K. Y. (2013). Corporate Governance and impact on Bank Performance. Journal of Finance and Accounting. Vol. 1, No. 1, 2013, pp. 19-26.

[25] Fiordelisi , Franco, David Marques-Ibanez and Phil Molyneux, 2010, "Efficiency and risk in European Banking", Working Paper Series No. 1211 / June 2010. European Central Bank.

[26] Frederick, W., Post, J., \& St. Davis, K.. (1992). Business and society: Corporate strategy, public policy, ethics. (7th ed.). McGraw-Hill, New York
[27] Gedajlovic, E., T. Yoshikawa, and M. Hashimoto. 2004. "Ownership structure, investment behavior and firm performance in Japanese manufacturing industries". Organization Studies 25 (8):1363-92.

[28] Gupta, Monika, \& Namita, Rajput.(2011). "Assessing the efficiency of foreign banks In Indian Context”. Banks and Banks Systems. Vol. 6(2).2011 Business Perspectives.

[29] Hadad, MD. Santoso, W. Mardanugraha, E. and

[30] Illyas, D. 2003. "Analysis of Indonesian Banking Efficiency: Application of Non Parametric Data Envelopment Analysis (DEA)". Jurnal Bank Indonesia.

[31]

[32] Hajer, Cheni \&Anis, Jarboui(2016). "Analysis of the Impact of Governance Bank Performance: Case of Commercial Tunisia”. Journal of Knowledge Economy, pp.1-25. 11 April 2016.

[33] Hasan,I., and R.Xie.(2013).Foreign bank entry and bank corporate governance in China. Emerging Markets Finance and Trade 49(2):4-18.

[34] Hermalin, B. E., \& Weisbach, M. S. (2003). "Boards of Directors as an endogenously determined institution: A survey of the economic literature". FRBNY Economic Policy Review, 4, 7-26

[35] Havrylchyk, O., (2006), Efficiency of the Polish Banking Industry: Foreign versus Domestic Banks, Journal of Banking and Finance, 30 1975-1996.

[36] Iftekhar Hasan \& Ru Xie (2013). “ Foreign Bank Entry and Bank Corporate Governance in China”, Emerging Markets Finance and Trade, 49:2, 4-18

[37] International Monetary Fund. (2018). "Bank Non performing loans to total gross Loans(\%). Global Financial Stability Report. International Finance Corporation. "The Indonesia Corporate Governance Manual'. First Edition. January 2014

[38] Kang, J.-K., and J.-M. Kim. 2010.” Do foreign investors exhibit a corporate governance disadvantage? An information asymmetry perspective". Journal of International Business Studies 41:1415-38.

[39] Lin, X., and Y. Zhang. 2009. "Bank ownership reform and bank performance in China". Journal of Banking \& Finance 33:20-2

[40] Lensink, Robert, R.,Meesters, and Naaborg, Iko.(2008)." Bank Efficiency and Foreign Ownership: Do Good Institutions Matter?", Journal of Banking \& Finance 32(5):834-844

[41] María Eugenia, Delfino.2007. "Control Changes and Firm Performance in Banking", International Journal of the Economics of Business, 14:2, 261-281

[42] McAllister and McManus (1993; in Ianotta, Giuliano, Giacomo Nocera dan Andrea Sironi, 2006, "Ownership Structure, Risk and Performance in the European Banking Industry working paper has presented at a Bocconi University seminar.

[43] Meyer, K. E., S. Estrin, S. K. Bhaumik, and M. W. Peng. 2009. Institutions, resources and entry strategies in emerging economies. Strategic Management Journal 30:61-80.

[44] Ozili, Peterson Kitakogelu, Uadiale, Olayinka.(2017). "Ownership concentration and bank Profitability.” Future Business Journal 3 (2017) 159

[45] Pindyck, Robert.S and Daniel L Rubinfeld, 1995, Microeconomic, edition 3, China.Prentice-Hall.

[46] Putri, VR. and Lukviarman, N. 2008. "Pengukuran Kinerja Bank Komersial Dengan Pendekatan Efisiensi, Studi Terhadap

[47] Perbankan Go-Public di Indonesia". Journal JAAI, Volume 12 (1)

[48] Phung, D. N., and T. P. V. Lee. 2013. Foreign ownership, capital structure and firm performance: Empirical evidence from Vietnamese listed firms. The IUP Journal of Corporate Governance 12 (2):40-58

[49] Rachdi, Houssem; Trabelsi;Mohamed Ali;Trad, Naama (2013). "Bank Specific Determinants of Credit Risk: Empirical Evedence from Tunisian banking Industry". Review of Economic Perspectives, Vol.13(4), Dec. 2013

[50] Rofikoh Rokhim \& Anindya P.Susanto.(2013). "The Increase in Foreign Ownership and its Impact on the Performance, Competition and Risk in the Indonesian Banking Industry "Asian Journal of Business and Accounting, 6(2),137-154.

[51] Rose, P.S. and S.C.Hudgins.(2013)."Bank Management and Financial Services.New York:Mc Graw Hill.

[52] Saha, A., Ahmad, N. H. and Dash, U. (2015). Drivers of technical efficiency in Malaysian banking: a new empirical insight. Asia Pac Econ Lit, 29: 161-173. doi:10.1111/apel.12091

[53] Shaher, T.A., Kasawneh, O., Salem, R. (2011), The Major Factors that Affect Banks' Performance in Middle Eastern Countries.Journal of Money, Investment and Banking, 20, 101-109

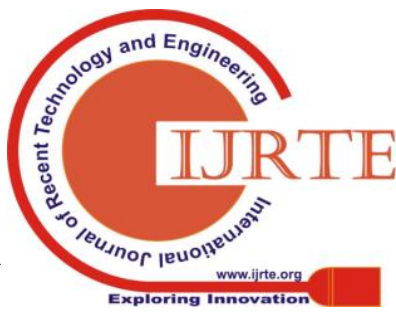




\section{Foreign Shareholdings Impact on Banks Efficiency and Moderating Role of Corporate Governance}

[54] Soba, M., Erem, I., and Ceylan, F. (2016). "The impact of corporate governance practices on bank efficiency: A case of Turkey". Journal of Suleyman Demirel University Institute of Social Science, 25(3):305-3

[55] Sok-Gee Chan, Eric H. YKoh and Yong-Cheol Kim (2016), ” Effect of Foreign Shareholdings and Originating Countries On Banking Sector Efficiency, Emerging Market Finance Trade", Routledge, Taylor \& Francis Group ISSN 1540-498X

[56] Sun, L., Chang, T.P.(2011). A comprehensive analysis of the effects of risk measures on bank efficiency: Evidence from emerging Asian countries Journal of Banking and Finance, 35, 1727-35

[57] Uang, Jinn-Yan., dan Chermian Eforis. (2015)." Corporate Governance and Firm Performance: The Moderating Effect of State Ownership". Proceedings of 4th Global Business and FinanceResearch Conference 25 - 27 May 2015. Melbourne, Australia ISBN: 978-1-922069-76-4

[58] Wahyuni, S., and M. A. Prabowo. 2012." Corporate control and firm performance: Does the type of owners matter?" Interdisciplinary Journal of Research in Business 2 (3):23-33.

[59] Whitley, R., and P. Kristensen. 1996. "The changing European firm: Limits to convergence". London: Routledge.

[60] Wooldridge, J. M. (2010)," Econometric analysis of cross section and panel data", MIT press.

[61] World Bank, "Foreign Entry Affect the Domestic Banking Market?" World Bank Policy Research Working Papers No 1918, June 1998.

[62] Wu, H.-L., C.-H. Chen, and M.-H. Lin. 2007. "The effect of foreign bank entry on the operational performance of commercial banks in the Chinese transnational economy. Post-Communist Economy 1(3):343-57 1

[63] Wu, Ching-Chih; Lin,Bing-Huei; and Yang Tung-Hsiao (2016). "How do Agency Problems Affect the Implied Cost of Capital?'Journal of Reviews on Global Economics. Vol. p .210-226

\section{AUTHORS PROFILE}

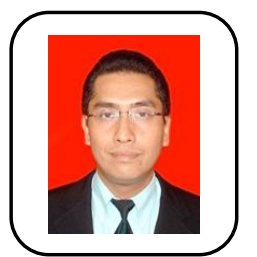

Aswin Rivai graduated from Faculty Economics University of Indonesia majoring in Industrial Economics, obtained Master of Management in Banking from Perbanas Institute Jakarta and currently Doctorate Candidate at Faculty of Economics and Business at Padjadjaran University. His research works has been published in International Journal and Proceedings. He periodically present his research works in International Economics and Business Conference in Malaysia, Kazakhstan, India, Japan, and Cyprus and actively participate in the IMF/World Bank Meetings and other ancillary meetings and seminars domestic and overseas. He has 22 years experience working in various global multinational banks and also an independent banking/financial consultant for World Wildlife Fund and Lecturer at STIMA IMMI Jakarta.

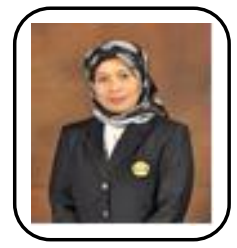

Prof. Dr. Rina Indiastuti is a professor in economics and a senior lecturer at the Department of Economics, Padjadjaran UniversProf. Indiastuti earned her bachelor in economics from from Osaka Prefecture University, Japan (1999). Prof. Indiastuti's research interest lies in the area of industry and banking. She is currently acting rector of Padjadjaran University. Prof. Indiastuti earned her bachelor in economics from Padjadjaran University (1984), a masters in industrial management from Bandung Institute of Technology, Indonesia (1989), and a Ph.D in economics from Osaka Prefecture University, Japan (1999). Prof. Indiastuti's research interest lies in the area of industry and banking. She is currently acting rector of Padjadjaran University.

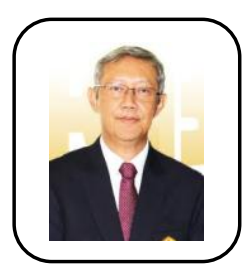

Prof. Dr. Nury Effendi is a professor in economics at the Department of Economics, Faculty of Economics and Business, Padjadjaran University. He earned his bachelor in economics from Padjadjaran University (1983), a Masters degree in economics from Ohio State University, USA (1987), and a Ph.D in economics from Oklahoma University, USA (2000). His research interest is in the area of financial economics and econometrics. His recent research is on the impact of corporate actions on public perception and on regional competitiveness in Indonesia. Dr. Nury Effendi is currently the Dean of the Faculty of Economics and Business, Padjadjaran University. His research work has been published in various international journals.

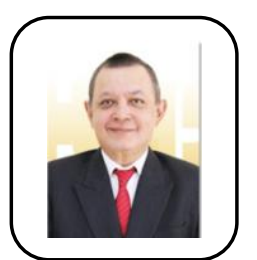

Dr. Achmad Kemal Hidayat is a senior lecturer and researcher at the Department of Economics, Padjadjaran University. He has been a researcher at CEDS since 1983. Dr. Hidayat earned his bachelor degree in economics and development study from Padjdajaran University, Indonesia (1983), a masters degree in rural regional planning from Asian Institute of Technology, Thailand (1986), and a Ph.D in financial economics from Padjadjaran University, (2007). Dr. Hidayat's research interest is in the area of finance and development of macro economic indicators. His recent research topic is on the development of monthly index of consumption and broader area of financial economics. Dr. Hidayat is currently the head of doctoral program in applied economics, Padjadjaran University. His research work has been published in various international journals.

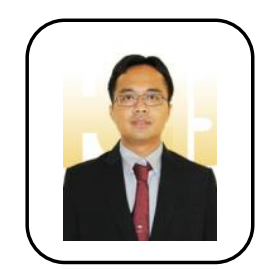

Dr. Maman Setiawan is a Lecturer and researcher at the Department of Economics, Padjadjaran University. He has been a researcher at CEDS since 2001. Mr. Setiawan earned his bachelor degree in Economics from Padjadjaran University, Indonesia (2001), a Masters degree in Industrial Management from Bandung Institute of Technology, Indonesia (2004), and a Ph.D in economics from Wageningen University, Netherland (2012). Dr. Setiawan's research interest is in the area of Industrial Economics and his recent research topic is on Market Structure, Price Rigidity, and Industrial Performance of Food and Beverages Industry. Currently Dr. Maman is the Head of Economics Universitas Padjadjaran 


\section{APPENDIX A:}

Descriptive Statistics

\begin{tabular}{|c|c|c|c|c|c|c|c|c|c|c|}
\hline & RGDP & LNASSET & \begin{tabular}{|c|} 
INFLATIO \\
$\mathrm{N}$ \\
\end{tabular} & $\begin{array}{c}\text { EFFICIEN } \\
\text { CY } \\
\end{array}$ & $\begin{array}{c}\text { CGDDE } \\
\mathrm{V}\end{array}$ & $\begin{array}{c}\text { CGDDEV } \\
\text { ING }\end{array}$ & CGD & CAR & DEV & DEVING \\
\hline Mean & 5.703480 & 13.06456 & 6.411661 & 0.728188 & 329.4113 & 274.7985 & 10.14107 & 31.74069 & 0.627585 & 0.229404 \\
\hline Median & 6.010000 & 13.12130 & 6.590000 & 0.700000 & 7.915200 & 0.000000 & 9.000000 & 19.70000 & 0.920000 & 0.000000 \\
\hline Maximum & 6.490000 & 16.53544 & 11.06000 & 1.000000 & 102928.0 & 87076.00 & 21.00000 & 206.6100 & 0.997000 & 1.000000 \\
\hline Minimum & 4.630000 & 8.284685 & 3.020000 & 0.115000 & 0.000000 & 0.000000 & 4.000000 & 9.410000 & 0.000000 & 0.000000 \\
\hline Std. Dev. & 0.717070 & 0.845179 & 2.887017 & 0.219005 & 5762.485 & 4875.218 & 3.595355 & 30.91938 & 0.438050 & 0.389798 \\
\hline
\end{tabular}

\begin{tabular}{|l|c|c|c|c|c|c|}
\hline & CHINA & CGFCHINA & CGFDEV & CGFDEVING & CGF & CGDCHINA \\
\hline Mean & 0.033503 & 0.106736 & 140.2556 & 74.81759 & 3.504702 & 0.285901 \\
\hline Median & 0.000000 & 0.000000 & 0.000000 & 0.000000 & 3.000000 & 0.000000 \\
\hline Maximum & 0.986100 & 3.944400 & 44112.00 & 23748.00 & 11.00000 & 9.861000 \\
\hline Minimum & 0.000000 & 0.000000 & 0.000000 & 0.000000 & 0.000000 & 0.000000 \\
\hline Std. Dev. & 0.177654 & 0.581572 & 2469.688 & 1329.612 & 2.066309 & 1.532210 \\
\hline
\end{tabular}

\begin{tabular}{|l|c|c|c|c|c|c|}
\hline & CGDDEV & CGDDEVING & CGD & CAR & DEV & DEVING \\
\hline Mean & 329.4113 & 274.7985 & 10.14107 & 31.74069 & 0.627585 & 0.229404 \\
\hline Median & 7.915200 & 0.000000 & 9.000000 & 19.70000 & 0.920000 & 0.000000 \\
\hline Maximum & 102928.0 & 87076.00 & 21.00000 & 206.6100 & 0.997000 & 1.000000 \\
\hline Minimum & 0.000000 & 0.000000 & 4.000000 & 9.410000 & 0.000000 & 0.000000 \\
\hline Std. Dev. & 5762.485 & 4875.218 & 3.595355 & 30.91938 & 0.438050 & 0.389798 \\
\hline
\end{tabular}

\section{APPENDIX B:}

The efficiency of local banks acquired by foreign shareholders 2007-2017

\begin{tabular}{|c|c|c|c|c|c|c|c|c|c|c|c|}
\hline BANK & 2007 & 2008 & 2009 & 2010 & 2011 & 2012 & 2013 & 2014 & 2015 & 2016 & 2017 \\
\hline AMAR & 0.54 & 0.539 & 0.539 & 1 & 1 & 0.452 & 1 & 1 & 0.588 & 1 & 1 \\
\hline OKE & 0.514 & 0.558 & 0.558 & 0.361 & 0.36 & 0.125 & 0.544 & 0.544 & 0.394 & 0.44 & 0.875 \\
\hline JTRUST & 0.63 & 0.567 & 0.567 & 1 & 1 & 0.443 & 0.671 & 0.671 & 0.351 & 0.528 & 0.843 \\
\hline MAYBANKSYAR & 0.362 & 0.537 & 0.537 & 1 & 1 & 0.447 & 1 & 1 & 1 & 0.516 & 1 \\
\hline METRO/SHINHAN & 0.864 & 0.774 & 0.774 & 0.521 & 0.521 & 0.115 & 0.582 & 0.582 & 0.474 & 0.484 & 0.806 \\
\hline WINDU/CCB & 0.588 & 0.529 & 0.529 & 0.543 & 0.543 & 0.369 & 0.693 & 0.693 & 0.534 & 0.559 & 0.645 \\
\hline SMBC & 0.706 & 0.771 & 0.771 & 1 & 1 & 1 & 1 & 1 & 1 & 1 & 1 \\
\hline MIZUHO & 1 & 0.871 & \begin{tabular}{|l|}
0.871 \\
\end{tabular} & 1 & 1 & 0.904 & 1 & 1 & 0.985 & 0.861 & 1 \\
\hline ANZ & 1 & 1 & 1 & 0.58 & 0.58 & 0.816 & 1 & 1 & 1 & 1 & 1 \\
\hline COMMONWEALTH & 1 & 1 & 1 & 0.353 & 0.353 & 0.655 & 0.497 & 0.497 & 0.561 & 0.477 & 0.777 \\
\hline DBS & 0.712 & 0.524 & 0.524 & 0.546 & 0.546 & 0.483 & 0.844 & 0.844 & 0.643 & 1 & 0.94 \\
\hline ICBC & 0.596 & 0.509 & 0.509 & 0.695 & 0.695 & 0.422 & 0.966 & 0.966 & 0.692 & 1 & 1 \\
\hline OCBC & 0.702 & 0.601 & 0.601 & 0.564 & 0.564 & 0.417 & 0.719 & 0.719 & 1 & 0.792 & 0.946 \\
\hline KEB/HANA & 1 & 1 & 1 & 1 & 1 & 1 & 1 & 1 & 1 & 0.925 & 0.853 \\
\hline RABO & 0.577 & 0.563 & 0.563 & 0.425 & 0.425 & 0.169 & 0.543 & 0.543 & 0.454 & 0.538 & 0.569 \\
\hline UOB & 1 & 1 & 1 & 0.614 & 0.614 & 0.547 & 0.745 & 0.745 & 0.924 & 0.94 & 0.986 \\
\hline $\mathrm{BNP}$ & 0.588 & 0.527 & 0.527 & 0.846 & 0.846 & 0.255 & 0.679 & 0.679 & 0.544 & 0.525 & 0.552 \\
\hline BOII & 0.572 & 0.654 & 0.654 & 0.873 & 0.873 & 0.434 & 1.00 & 1.00 & 0.687 & 1.00 & 0.787 \\
\hline WOORI & 1 & 1 & 1 & 1 & 1 & 0.965 & 1 & 1 & 0.936 & 0.675 & 0.886 \\
\hline BNPPARIBAS & 0.639 & 1 & 1 & 0.913 & 0.913 & 0.579 & 0.903 & 0.903 & 0.644 & 1 & 1 \\
\hline
\end{tabular}


Foreign Shareholdings Impact on Banks Efficiency and Moderating Role of Corporate Governance

\begin{tabular}{|l|l|l|l|l|l|l|l|l|l|l|l|l|} 
EKONOMI & 0.654 & 0.654 & 0.654 & 0.543 & 0.543 & 1 & 0.675 & 0.675 & 0.532 & 0.53 & 1 \\
\hline CIMB & 0.617 & 0.552 & 0.552 & 0.611 & 0.611 & 0.406 & 0.795 & 0.795 & 0.646 & 0.74 & 0.961 \\
\hline QNBKESAWAN & 0.581 & 0.478 & 0.478 & 0.474 & 0.474 & 0.147 & 0.417 & 0.417 & 0.588 & 0.727 & 0.586 \\
\hline MUAMALAT & 0.611 & 0.918 & 0.918 & 0.476 & 0.476 & 0.202 & 0.738 & 0.738 & 0.547 & 0.546 & 0.76 \\
\hline BII/MAYBANK & 0.549 & 0.513 & 0.513 & 0.529 & 0.529 & 0.325 & 0.684 & 0.684 & 0.728 & 0.711 & 0.795 \\
\hline CTBC & 0.806 & 0.88 & 0.88 & 1 & 1 & 1 & 1 & 1 & 1 & 1 & 1 \\
\hline SBII & 0.601 & 0.572 & 0.572 & 0.668 & 0.668 & 0.491 & 0.941 & 0.941 & 0.705 & 0.925 & 0.941 \\
\hline RESONA & 0.704 & 0.738 & 0.738 & 0.768 & 0.768 & 0.518 & 1 & 1 & 0.817 & 0.908 & 0.791 \\
\hline DANAMON & 0.804 & 0.696 & 0.696 & 0.615 & 0.615 & 0.354 & 0.544 & 0.544 & 0.661 & 0.7 & 0.922 \\
\hline
\end{tabular}

\section{APPENDIX C:}

Matrix Correlation

\begin{tabular}{|l|c|c|c|c|c|c|c|}
\hline & RGDP & LNASSET & INFL & EFFICIENCY & CHINA & CGFCHINA & CGFDEV \\
\hline RGDP & $\mathbf{1 . 0 0 0 0 0 0}$ & -0.109961 & -0.021969 & -0.159201 & -0.001552 & -0.031225 & -0.054335 \\
\hline LNASSET & -0.109961 & $\mathbf{1 . 0 0 0 0 0 0}$ & -0.136948 & 0.048502 & 0.034611 & 0.040009 & 0.076723 \\
\hline INFL & -0.021969 & -0.136948 & $\mathbf{1 . 0 0 0 0 0 0}$ & 0.016752 & -0.001870 & -0.011401 & 0.037878 \\
\hline EFFICIENCY & -0.159201 & 0.048502 & 0.016752 & $\mathbf{1 . 0 0 0 0 0 0}$ & 0.001719 & 0.021324 & -0.047107 \\
\hline CHINA & -0.001552 & 0.034611 & -0.001870 & 0.001719 & $\mathbf{1 . 0 0 0 0 0 0}$ & 0.974417 & -0.010744 \\
\hline CGFCHINA & -0.031225 & 0.040009 & -0.011401 & 0.021324 & 0.974417 & $\mathbf{1 . 0 0 0 0 0 0}$ & -0.010456 \\
\hline CGFDEV & -0.054335 & 0.076723 & 0.037878 & -0.047107 & -0.010744 & -0.010456 & $\mathbf{1 . 0 0 0 0 0 0}$ \\
\hline CGFDEVING & 0.061564 & 0.029586 & -0.051037 & -0.064745 & -0.010645 & -0.010360 & -0.003206 \\
\hline CGF & -0.044315 & 0.534027 & -0.062618 & 0.005154 & -0.029194 & -0.013931 & 0.068442 \\
\hline CGDCHINA & -0.010836 & 0.046869 & -0.013589 & 0.015640 & 0.988157 & 0.986594 & -0.010630 \\
\hline CGDDEV & -0.054783 & 0.077061 & 0.037356 & -0.046519 & -0.010905 & -0.010613 & 0.999963 \\
\hline CGDDEVING & 0.061649 & 0.029478 & -0.050956 & -0.064806 & -0.010663 & -0.010377 & -0.003211 \\
\hline CGD & -0.019792 & 0.552015 & -0.090474 & -0.128344 & -0.084588 & -0.072070 & 0.060859 \\
\hline CAR & -0.021057 & -0.517503 & 0.112409 & 0.118364 & 0.022431 & 0.012092 & -0.025522 \\
\hline DEV & -0.053346 & 0.058140 & -0.059782 & 0.091611 & -0.032008 & -0.031150 & -0.002025 \\
\hline DEVING & 0.079166 & -0.417072 & 0.107269 & -0.194032 & -0.111337 & -0.108351 & -0.033518 \\
\hline
\end{tabular}

\begin{tabular}{|l|c|c|c|c|c|c|c|c|c|}
\hline & CGFDEVING & CGF & CGDCHINA & CGDDEV & CGDDEVING & CGD & CAR & DEV & DEVING \\
\hline RPDB & 0.061564 & -0.044315 & -0.010836 & -0.054783 & 0.061649 & -0.019792 & -0.021057 & -0.053346 & 0.079166 \\
\hline ROA & -0.002199 & 0.113844 & -0.045785 & 0.006691 & -0.002184 & 0.075701 & 0.123442 & 0.057514 & -0.257916 \\
\hline NPL & -0.001710 & -0.090912 & -0.060458 & -0.005786 & -0.001663 & -0.037701 & -0.100627 & -0.010486 & 0.220796 \\
\hline LNASSET & 0.029586 & 0.534027 & 0.046869 & 0.077061 & 0.029478 & 0.552015 & -0.517503 & 0.058140 & -0.417072 \\
\hline INFL & -0.051037 & -0.062618 & -0.013589 & 0.037356 & -0.050956 & -0.090474 & 0.112409 & -0.059782 & 0.107269 \\
\hline EFFICIENCY & -0.064745 & 0.005154 & 0.015640 & -0.046519 & -0.064806 & -0.128344 & 0.118364 & 0.091611 & -0.194032 \\
\hline CHINA & -0.010645 & -0.029194 & 0.988157 & -0.010905 & -0.010663 & -0.084588 & 0.022431 & -0.032008 & -0.111337 \\
\hline CGFCHINA & -0.010360 & -0.013931 & 0.986594 & -0.010613 & -0.010377 & -0.072070 & 0.012092 & -0.031150 & -0.108351 \\
\hline CGFDEV & -0.003206 & 0.068442 & -0.010630 & 0.999963 & -0.003211 & 0.060859 & -0.025522 & -0.002025 & -0.033518 \\
\hline CGFDEVING & $\mathbf{1 . 0 0 0 0 0 0}$ & -0.013650 & -0.010533 & -0.003254 & 1.000000 & 0.013376 & -0.035794 & -0.009550 & 0.081400 \\
\hline CGF & -0.013650 & $\mathbf{1 . 0 0 0 0 0 0}$ & -0.022116 & 0.068335 & -0.014002 & 0.755691 & -0.306859 & 0.020666 & -0.516484 \\
\hline CGDCHINA & -0.010533 & -0.022116 & $\mathbf{1 . 0 0 0 0 0 0}$ & -0.010790 & -0.010551 & -0.073342 & 0.002900 & -0.031670 & -0.110160 \\
\hline CGDDEV & -0.003254 & 0.068335 & -0.010790 & $\mathbf{1 . 0 0 0 0 0 0}$ & -0.003259 & 0.060781 & -0.025730 & 0.006604 & -0.034023 \\
\hline CGDDEVING & 1.000000 & -0.014002 & -0.010551 & -0.003259 & $\mathbf{1 . 0 0 0 0 0 0}$ & 0.013270 & -0.035759 & -0.009567 & 0.081625 \\
\hline CGD & 0.013376 & 0.755691 & -0.073342 & 0.060781 & 0.013270 & $\mathbf{1 . 0 0 0 0 0 0}$ & -0.431218 & 0.003553 & -0.320204 \\
\hline CAR & -0.035794 & -0.306859 & 0.002900 & -0.025730 & -0.035759 & -0.431218 & $\mathbf{1 . 0 0 0 0 0 0}$ & -0.021740 & 0.102998 \\
\hline DEV & -0.009550 & 0.020666 & -0.031670 & 0.006604 & -0.009567 & 0.003553 & -0.021740 & $\mathbf{1 . 0 0 0 0 0 0}$ & -0.098473 \\
\hline DEVING & 0.081400 & -0.516484 & -0.110160 & -0.034023 & 0.081625 & -0.320204 & 0.102998 & -0.098473 & $\mathbf{1 . 0 0 0 0 0 0}$ \\
\hline
\end{tabular}

